\title{
Momentum, December 2005
}

Population Council

Follow this and additional works at: https://knowledgecommons.popcouncil.org/ series_newsletters_momentum How does access to this work benefit you? Let us know!

\section{Recommended Citation}

"Momentum, December 2005," newsletter. New York: Population Council. 


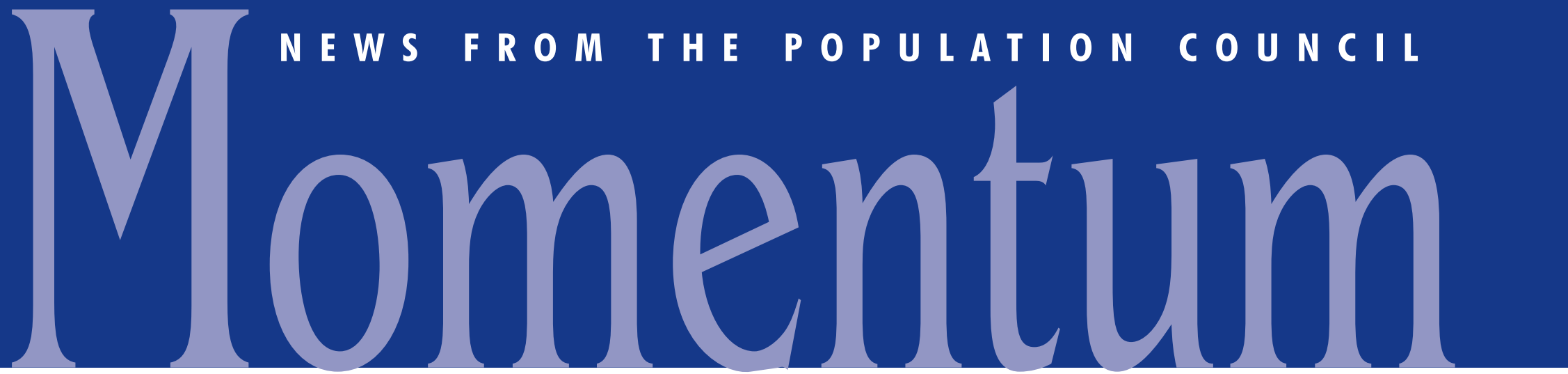

DECE M B E R 2005

\section{The Navrongo Experiment}

$\mathrm{F}$ OR TWO DECADES, THE GHANA MINISTRY OF HEALTH placed priority on community-based primary health care and family planning services. National programs were launched for deploying volunteers and community health nurses to communities, but by 1992 it was evident that the programs were not functioning as planned. Volunteers were inadequately supervised and the quality of service was poor. While 2,000 nurses had been hired, trained, and deployed to subdistrict clinics, the care offered at the clinics was inaccessible to most rural families.

In 1994, the Ghana Ministry of Health established the Navrongo Health Research Centre in northeastern Ghana to improve access to reproductive and child health services in impoverished communities. By 1996, differing strategies were being tested to determine how best to launch and sustain community health services: services provided by community-based nurses working alone, volunteers working alone, and nurses and volunteers working together. Conventional Ministry of Health clinical services were also provided in all areas of the study district, including those not receiving resident nurse or volunteer care.

Strategies for training and community involvement were designed to improve the quality of volunteer services. Engaging community members in construction and

continued next page

\section{The MDGs: New Perspectives from Experienced Practitioners}

A special issue of the Population Council's peerreviewed journal Studies in Family Planning published in June featured original essays by high-level UN staff, scholars, and international nongovernmental leaders on global efforts to achieve the Millennium Development Goals. The edition was developed in anticipation of the UN's 2005 World Summit in September to aid review of progress on meeting the goals. To learn more about how closely the Population Council's research aligns with the MDGs, visit www.popcouncil.org/about/MDGs.html.

\section{AN MDG THAT CAN BE MET}

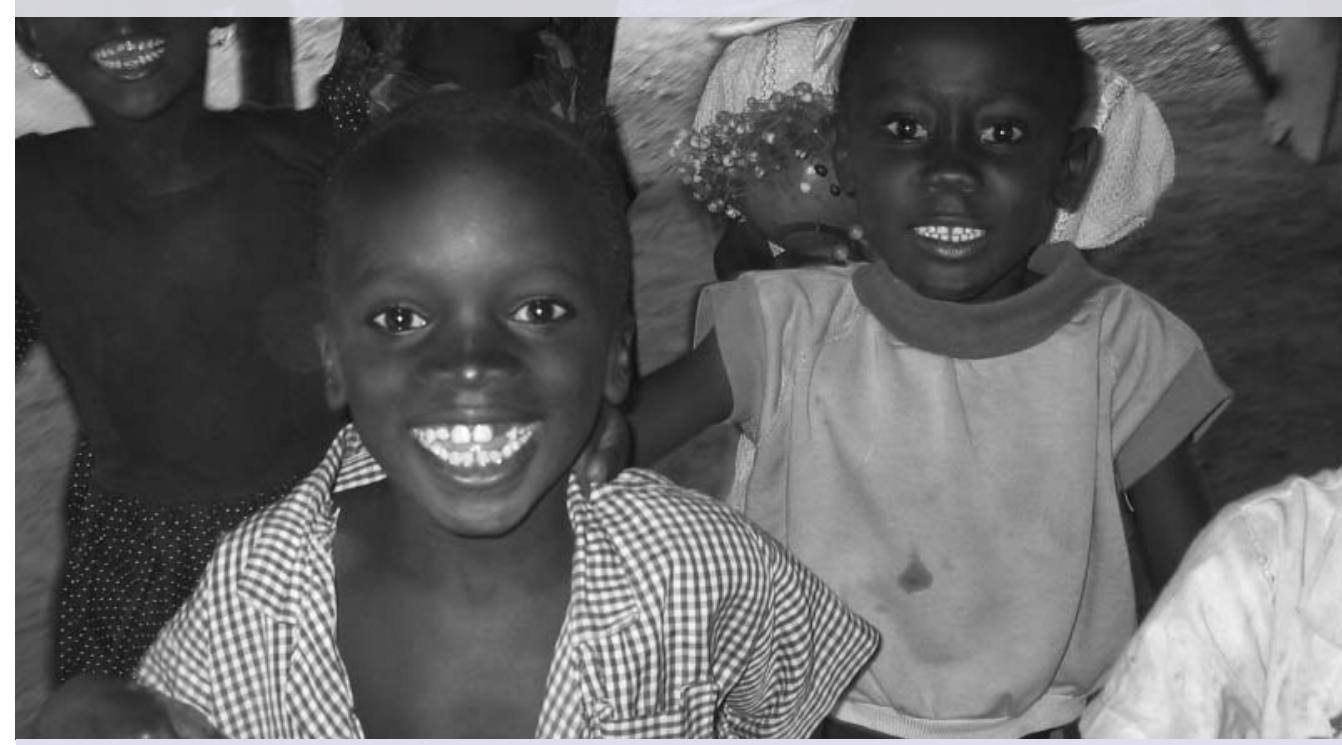

N SEPTEMBER 2000, UNITED NATIONS MEMBERS OUTLINED EIGHT MILLENNIUM DEVELOPMENT GOALS (MDGs) to reduce poverty and improve people's lives; 191 member states pledged to meet these goals by 2015 . One MDG calls for reducing the mortality rate among children under age five by two-thirds within this 15 -year timeframe.

Children born in low-income countries are 13 times more likely to die before their third birthday than children born in high-income countries. Over half of the ten million under-age-five children who die each year are in sub-Saharan Africa, where only 14 percent of the world's children reside.

In one of the poorest and most remote regions of Ghana, in the Kassena-Nankana district where the Navrongo Health Research Centre is located, the under-five mortality rate has declined consistently from 188 deaths per thousand in 1993 to 79 in 2003-a 58 percent drop in ten years.

The Population Council's collaborative research with the Navrongo Centre has demonstrated that deploying community nurses to village locations can accelerate this decline, cutting childhood mortality rates by two-thirds in only six years. After this strategy was proven replicable in a similarly poor, rural, but nonresearch setting, the Government of Ghana made the commitment to scale up the service model (see "The Navrongo Experiment").

In 2005, representatives of community health programs in Burkina Faso, Ethiopia, and Sierra Leone met in Navrongo with their Ghanaian counterparts to review the relevance of findings from the Navrongo research for health development in other African countries. They formed a steering committee for ExCHANGE, a network to share ideas on expanding community health care accessibility. A compendium of papers is being prepared to document the success of the project's approach, its health and demographic effects, and its role in shaping national policy. The volume will set the stage for new research on the MDGs of reducing child mortality and of improving maternal health. 
support of facilities to house care providers enabled the project to relocate nurses to the communities and sustain accessible care at low cost. In communities where nurses were deployed, mortality rates under age five dropped by 50 percent in three years. Adding volunteers to this strategy improved family planning acceptability and reduced fertility by 15 percent. These results prompted adoption of a combined community-nurse and volunteer-outreach strategy as the model for national policy.

As an advisor to the Ghana Health Service, James Phillips, a Council senior research associate, is bridging the gap between research results and their practical application, including how best to build consensus for health service reforms at the national, regional, and community levels.

“The government of Ghana wanted to find ways of solving the service quality and accessibility problems," says Phillips. "But, given past problems with poorly planned, large-scale programs, they wanted to focus attention on launching a trial that could guide development of their health-care delivery system."

Replication of the Navrongo model in the Nkwanta District was launched in 2000 to test the transfer of lessons learned to a nonresearch setting. This project demonstrated that the Navrongo approach to service delivery was replicable as long as accommodation was made for differences in prevailing customs and resources. The emphasis on what worked and what failed (see right) made successful scale-up possible.

On the basis of those results, the Ministry of Health adopted the Navrongo model as an integral component of its national poverty-reduction strategy. In 2000 the Ghana Health Service launched the Community-based Health Planning and Services (CHPS) initiative, with Phillips serving as advisor. CHPS mobilizes volunteers, resources, and cultural institutions to support delivery of community-based, primary health-care services throughout Ghana. CHPS has been fully implemented in 20 communities within Ghana's 138 districts.

In September, Phillips and Council Berelson Fellow Ayaga Bawah presented findings from the CHPS initiative to senior officials of the United States Agency for International Development (USAID), which recently awarded the Council a five-year grant to assist the Ghanaian Government in the scale-up of the Navrongo model. The presentation, entitled "The design, impact, and utilization of the Navrongo Experiment in Northern Ghana," is set for publication in the Population Council Working Paper series.

The Council's work in Ghana is funded by The William and Flora Hewlett Foundation, The Andrew W. Mellon Foundation, and USAID.

\section{On-the-ground Dissemination}

W

\section{HAT WORKS? WHAT FAILS?}

(WWWF) is a publication that has charted and helped guide the evolution of the Navrongo Experiment into a national health-care delivery system. Growing from an informal paper newsletter to a series of 90plus online issues, WWWF shares firsthand knowledge about the process of making primary health care widely accessible to rural people. Lessons from Navrongo and Nkwantaespecially how services were influenced by community opinion, reaction, and advice-are invaluable to the Ghanaians who are scaling up the initiative across their country, and useful for international readers seeking to learn how to foster reform in their countries. Of primary importance are the mechanisms it illuminates for consensus building. WWWF was created in 2001, and Santuah Niagia, Population Council communications specialist and WWWF editor, joined the Council soon afterward.

“Communication is considered absolutely vital to building consensus for organizational change," says Niagia. "Communities, service providers, and managers develop a real sense of ownership when they are allowed-invited-to participate. What works? What fails? is a road map of how we got from there to here, but it is also a guide for making your own maps of your local terrain."

Each 1,000-word newsletter contains one article in an easy-to-read format featuring a picture or two. Early issues record how Navrongo evolved by interviewing residents, traditional leaders, nurses, local health volunteers and committee members, government workers, and even a local soothsayer or two. Although Niagia does most of the writing, contributors have ranged from principal investigators to chiefs to volunteers.
Paper copies are distributed locally to all local chiefs, community health officers, volunteers, and health committees, and are mailed to the country's 138 districts and to nurse training institutions, universities, public and institutional libraries, and elsewhere in Ghana, across Africa, and around the world. Copies are also e-mailed to some 300 recipients worldwide.

Every year, Niagia arranges the 24 or so new issues by theme in an electronic volume; he is currently assembling all of the issues into a single compendium. All issues are available on the USAID Web site. To join the electronic distribution list, e-mail what_works?@ navrongo.mimcom.net.

What works? What fails? was made possible through support provided by the Office of Population and Reproductive Health, Bureau for Global Health, USAID, and the Bill \& Melinda Gates Foundation.

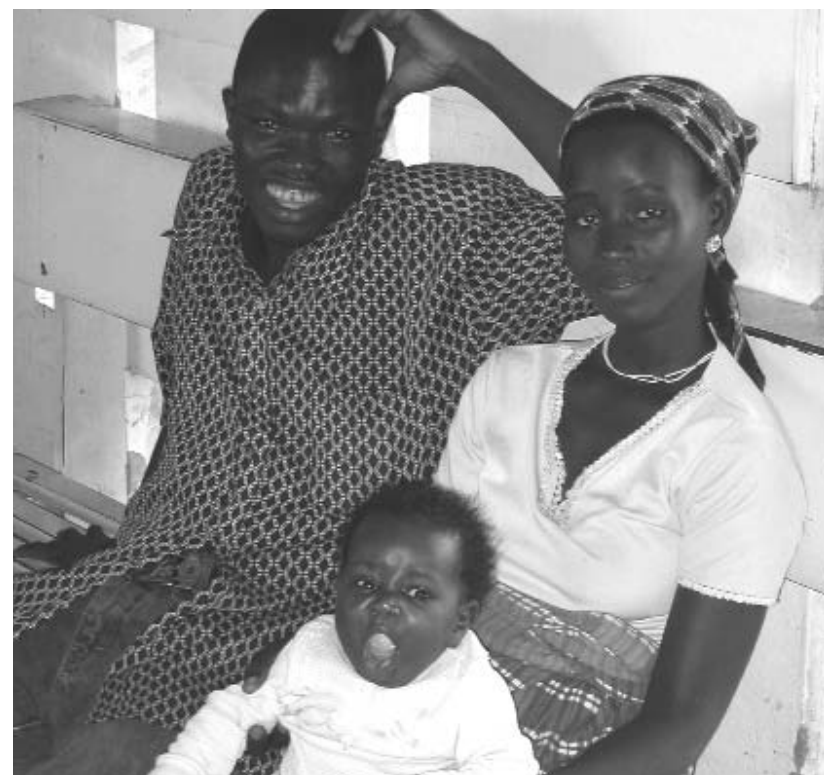

\section{African Dreams}

$\mathrm{S}$ ANTUAH NIAGIA (pictured below, left) traveled to Cuenca, Ecuador, in July to present his prize-winning paper on "Innovative Strategies for Bridging Health Inequality Gaps" at the Second People's

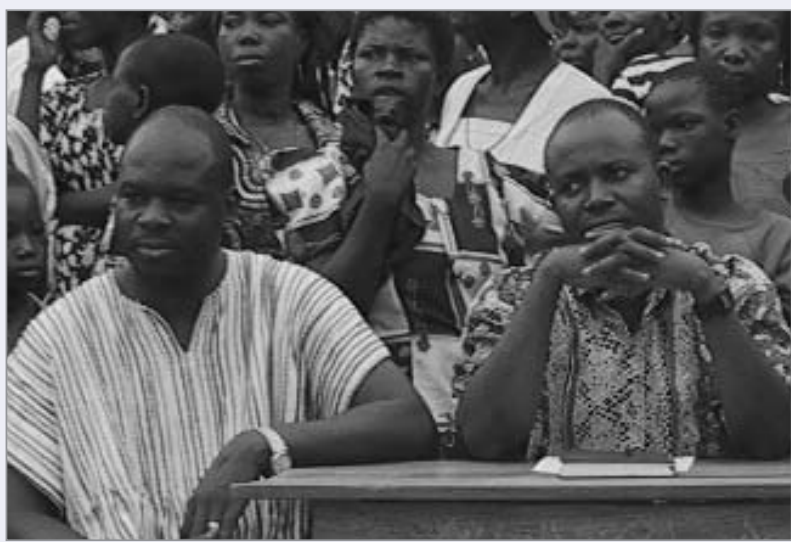

Health Assembly, convened by the People's Health Movement.

This paper, which Niagia submitted for the African Dreams Essay Competition 2004-2005, was based on his work for the Navrongo Health Research Centre (see above). His essay won first prize, including a cash award that allowed him to deliver his paper in person.

The meeting provided an opportunity to share the Navrongo experience with other activists in healthrelated sectors worldwide. Nearly 1,400 participants from 80 countries attended the conference.

Niagia's essay in its entirety is available at www.popcouncil.org/ africa/santuah.html. 


\section{Sowing Innovation}

A S RECENT EVENTS have demonstrated, the magnitude of natural disasters-whether hurricane, tsunami, earthquake, or flood-is amplified by poverty. In communities already coping with tremendous challenges, women's contributions to recovery can make a critical difference. "Women's Participation in Disaster Relief and Recovery," the latest issue of the SEEDS pamphlet series, underscores what local women accomplished after earthquakes struck their communities in India and Turkey. SEEDS is widely distributed throughout the developing world and is available electronically online at www.popcouncil.org/seeds.

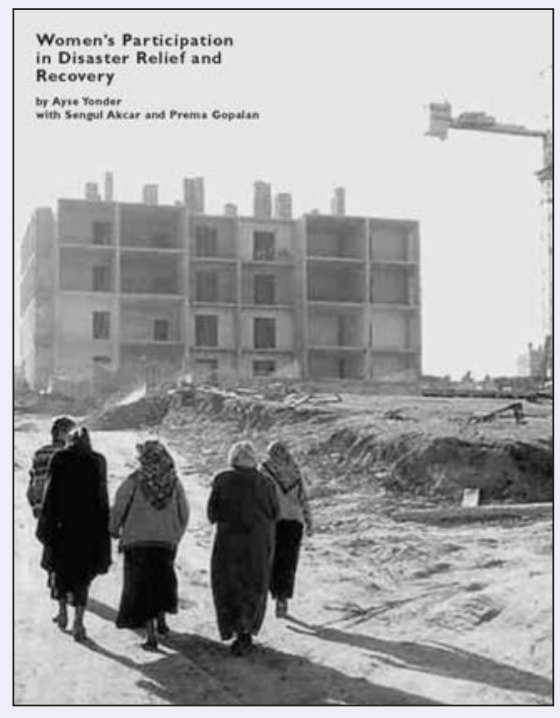

I am writing to share with you how significant and useful the SEEDS publication "Are We Not Peasants Too?," by Bina Agarwal, has proved for innumerable organisations and individuals in our region. In fact, the usefulness of this publication cannot be overstated. Our organisation-Sathi All for Partnerships, Consult for Women and Land Rights-and our many partners have used it like a primer for spreading awareness on the issue of women and land rights both locally and globally.

We have used this publication in workshops at the village level, for training NGO activists, and for lobbying the government and international agencies, so that they take up this issue in action and policy. Since it is available both in English and in the Hindi translation published here (as also in Gujarati), it has had an extensive reach and impact.

The village women consider the volume their prized possession. I have seen them carry the booklet in their bags for months after they have attended a workshop. They
The SEEDS series-now in its 25th yearwas developed by the Population Council to provide information about innovative, practical programs addressing the economic roles and needs of low-income women in developing countries. The pamphlets are designed to share knowledge and to spark new initiatives guided by what works in the real world. They describe the basis for actions and their implementation in the hope that the lessons learned can be useful to women facing similar circumstances.

Funded by the Ford Foundation, the series is moving from its original home at the Population Council to The New School's Graduate Program in International Affairs. The transition to The New School is an important capacity-building initiative that will give young practitioners entering the field of international development broader knowledge of strategies and policies for strengthening women's earning potential and improving their working and living conditions. Judith Bruce, program director for the Council's Gender, Family, and Development Program, will remain on the SEEDS advisory committee.

The impact of SEEDS is movingly described in excerpts from a July 2005 letter to Sandy Schilen, longtime editor of SEEDS, from Shivani Bhardwaj, Program Director, Sathi All for Partnerships, and Coordinator, Consult for Women and Land Rights, New Delhi:

carry it around even though they cannot read it, as they have memorized which page they may ask to be opened in a courtroom or during a village council (panchayat) meeting to get across the fact that women do have land rights....

Some days ago our Prime Minister received a letter from the National Advisory Council chaired by The President of Congress Party [saying] that land rights and inheritance rights, especially on agriculture land for women, needs to be an issue of priority for our government. This significant move has been a result of the hard work of many individuals which has been captured very successfully in the SEEDS publication. This body of knowledge has been turned into information that could be picked up to build an action agenda for activists and policy influencers.

The SEEDS publication has been a pioneer. Indeed it is a jewel in the documentation that helps strengthen positive approaches for the realization of women's right to agricultural land.

\section{Swahili Translation of Council Publication on Fistula Lauded}

A SWAHILI TRANSLATION of the Population Council's "Healing Wounds, Instilling Hope: The Tanzanian Partnership Against Obstetric Fistula" was introduced to a standing-room-only crowd at a meeting in October officiated by the Permanent Secretary of the Tanzanian Ministry of Health, Mariam J. Mwaffisi, in Dar es Salaam. Also available in English and French, this latest issue of the Council's Quality/Calidad/Qualité booklet series, written by Council program coordinator Erica Chong, documents the partnership formed by a hospital program, nongovernmental organizations, and the Tanzanian government to identify and treat women with fistula while also seeking to identify and address its root causes. The Swahili version was translated, printed, and distributed by the Women's Dignity Project of Tanzania.

Speakers at the two-hour event included Charles Majinge, director of the Bugando Medical Centre, who gave a presentation about the center's fistula program; nurse Yasinta Mkama, who related the story of a fistula patient in her care; and Maggie Banger, founding member of the Fistula Project at Bugando, who linked fistula to women's rights and issued a call for action to improve maternal health.

The launch and the booklet received extensive coverage by Tanzanian television, radio, and newspapers. It is available free at www.popcouncil.org/publications/qcq/ default.htm.

This edition of $\mathrm{Q} / \mathrm{C} / 0$ was partially funded by the United Nations Population Fund (UNFPA) and the Ford Foundation.

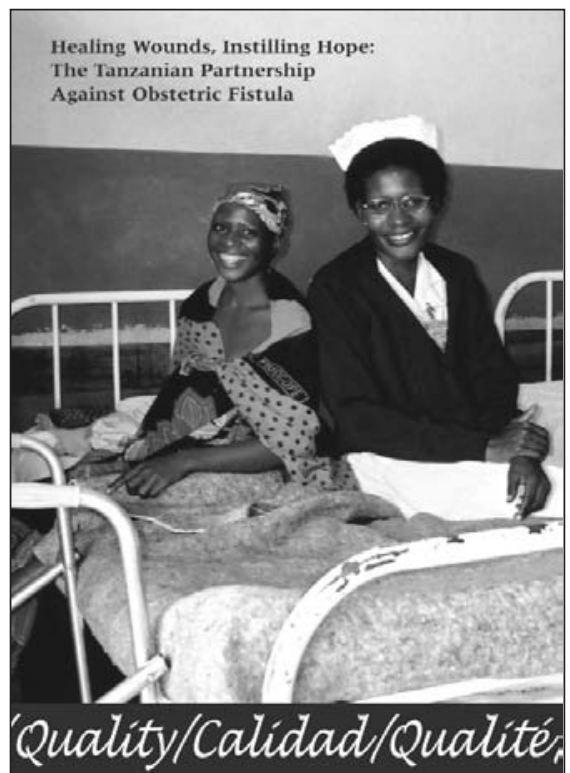




\section{Dissemination: Making Results Known}

Dissemination of the Population Council's findings takes many forms: meetings with policymakers and program managers around the world; presentations and distribution of findings at major public health, social science, and biomedical conferences; media briefings and interviews; publication of books, working papers, and in two internationally recognized, peer-reviewed journals, Population and Development Review and Studies in Family Planning; and on its Web site.

A June seminar in a series hosted by the Horizons Program and InterAction about the featured presentation, "Providing Psychosocial Support to Orphans and Vulnerable Children in the Context of the AIDS Epidemic and Tsunami Disaster," sought to create dialogue between organizations working with children in a variety of difficult settings. Information is available at www.popcouncil.org/horizons/mtgs/iap.

In August, the Council's regional office for Latin America and the Caribbean hosted its "Second Research Meeting on Unwanted Pregnancy and Unsafe Abortion" in association with local and international collaborating organizations. The three-day conference in Mexico City brought together 230 participants from 22 countries in the region.

An op-ed piece by Saroj Pachauri, regional director of the Council's South and East Asia Region, was published in The Indian Express, a Mumbai newspaper, shortly before the September 2005 UN World Summit. Pachauri urged that sexual and reproductive health $(\mathrm{RH})$ issues - omitted from the Millennium Development Goals yet profoundly influencing population issues-be included in the UN's 21st-century agenda. Asked to write a follow-up article, she was able to report that $\mathrm{RH}$ priorities had been added and acknowledged as essential to meeting the goals.

From April through August, Council program associate Judith Diers made presentations on child marriage and the "girls left behind" to a variety of faith-based organizations, including the annual meeting of Christian Connections for International Health, the Division for Global Missions of the Evangelical Lutheran Church in America, Wheaton College (an evangelical college), a Lutheran missionary conference, and others as part of "Reaching Out for Common Ground," an initiative funded by The Libra Foundation.

Cynthia B. Lloyd, the Council's director of social science research and editor of the National Academies report Growing Up
Global: The Changing Transitions to Adulthood in Developing Countries, has presented its findings to policymakers and social scientists in Mexico City, London, and New Delhi. In the last six months she has made two presentations to USAID, and one each at the World Bank and Woodrow Wilson Center. A congressional briefing is scheduled for the beginning of December.

Régine L. Sitruk-Ware, executive director of the Council's Product Research and Development program, chaired a session at the 11th World Congress on the Menopause symposium in Buenos Aires in October on "The meaning of individualized therapy for prescribers and patients," and delivered four papers.

Ragui Assaad, regional director for West Asia and North Africa, chaired a panel on "International databases and data sharing" at the Social Science Research Council's October conference, "Promoting International Cooperation in Social Science Research."

With underwriting from the John D. and Catherine T. MacArthur Foundation, the Council for the first time has posted information in Arabic on its Web site. The nearly 30 Arabic publications comprising over 1,300 pages - and expanded Spanishand French-language sections of the siteare accessible from www.popcouncil.org, which serves some 60,000 visits each month.

\section{Computerized Interviews: More Accurate Data?}

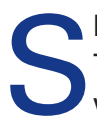
EXUALLY TRANSMITTED INFECTIONS (STIs), including infection with human immunodeficiency virus (HIV), the virus that leads to AIDS, have a devastating impact on women's health worldwide. Understanding who is at risk for STIs/HIV and what behaviors lead to infection is critical for developing and evaluating programs to prevent new infections and treat those already infected.

“Many individuals are uncomfortable answering questions about very personal and sensitive behaviors, for example how often they have sex, with whom, and under what circumstances," says Population Council senior researcher Barbara S. Mensch. "Unfortunately, if reporting of risky sexual activity is inaccurate, the ability to implement and monitor health programs is compromised and estimates of STI risk may be seriously biased."
To address this issue, Mensch, senior associate Paul C. Hewett, and program associate Heidi Jones have conducted research using audio-computerized self-interviewing (ACASI) technologies. Computerized selfinterviewing provides individuals greater privacy and confidentiality when responding to sensitive questions (see box).

\section{Getting Personal}

Instead of answering questions aloud in a faceto-face interview, a respondent using an ACASI computer hears pre-recorded questions through audio headphones and presses numbers on a numeric keypad to answer them. The computer can remain open, allowing the respondent to read the question along with the audio, or may be closed for complete privacy. Council researchers have found that most participants quickly learn how to use the interview program and prefer the computer over face-to-face interviews.

The critical question is whether computerized interviewing provides more accurate reporting of risky behaviors than traditional face-to-face interviews. Council researchers, in collaboration with Brazilian colleagues at the Centro de Saúde Escola Dr. Alexandre Vranjac, Barra Funda (CSEBF) health center, set out to answer this question by conducting a randomized experiment comparing the reporting of risky behaviors in computerized versus face-to-face interviews. This studyinvolving over 800 women in a low-income area of São Paulo who were receiving care and treatment at CSEBF-found that those interviewed using the computer were significantly more likely to report high-risk sexual activities, for instance a greater number of lifetime and overlapping sexual partners, as well as less condom use. ACASI respondents were also more likely to reveal that they and their partners had recently used alcohol or drugs, behavior often associated with highrisk sexual activity. The results of this study provide strong evidence of the benefits of computerized interviewing for reporting of sensitive behavior.

A broader program of research and evaluation on this topic has been initiated by Council researchers in countries with high rates of STIs and HIV/AIDS, including Kenya, Madagascar, Malawi, and Uganda. The cumulative results of these studies, and studies of alternative methods for collecting accurate information about populations in settings where computers may not be feasible, are helping researchers and program managers design more effective ways of collecting evidence crucial to improving reproductive health for both men and women.

Funding was provided by the National Institute of Child Health and Human Development (NICHD), USAID, and the Bill \& Melinda Gates Foundation. Future work on this topic will be funded by NICHD. 


\section{A "Win-Win" for Science}

$\mathrm{P}$ OPULATION COUNCIL SENIOR SCIENTIST MELISSA POPE conducts research on the immune system's dendritic cells at the Council's Center for Biomedical Research in New York. An awardwinning immunologist, Pope is working to define the role of these cells in HIV infection and has contributed to one of the major accepted theories for the mechanism of sexual transmission of HIV.

Six research fellows chosen on the basis of their academic accomplishments and experience are working with Pope on microbicide and HIV vaccine research. The fellows mention "great supervision" and a "wonderful environment to do science" when asked about their experiences. Pope says, "These fellowships are a 'win-win' for everyone: I get talented, enthusiastic collaborators, and the fellows get first-rate training they take with them to labs around the world."

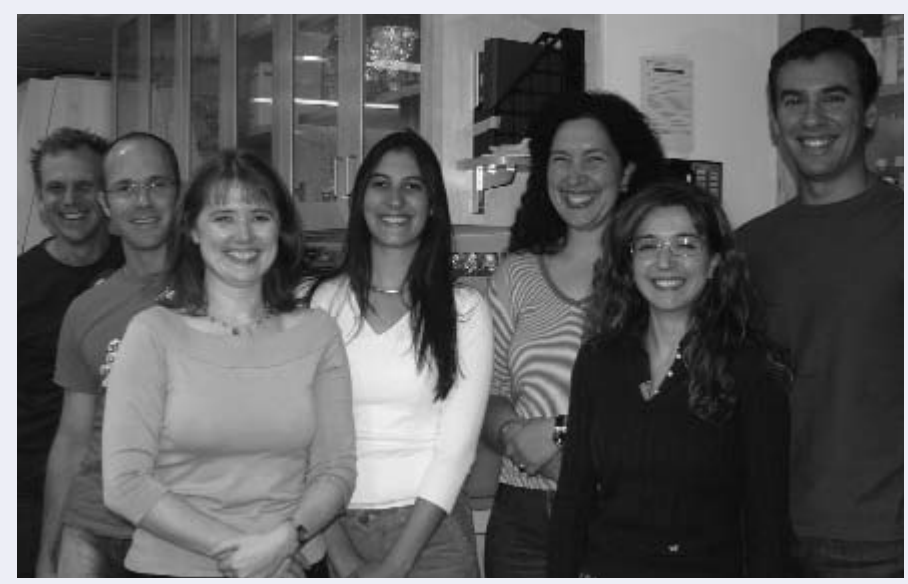

Pictured below, from left to right, are: Australian Ph.D. Stuart Turville, who investigates the biology of dendritic cell-driven HIV infection and tests compounds to block infection in vitro and in vivo; Gavin Morrow, an Australian with a Ph.D. from Sydney University, who studies mucosal innate and adaptive immune responses during immunodeficiency virus infection; Melissa Pope; Laurence Vachot, a French Ph.D. who is investigating how the co-pathogen Candida albicans interacts with dendritic cells in HIV infection; German Susanna Trapp, a Ph.D. from the University of Erlangen, who works on HIV modulation of dendritic cell functions and how this contributes to HIV transmission and tissue damage; Italian Ph.D. candidate Silvia Peretti, on exchange from the Superior Institute of Health in Rome, whose work examines the effects of a herpes simplex virus on the biology of dendritic cells and the role of dendritic cells in mucosal transmission; and Panagiotis Vagenas, a Greek with a Ph.D. in immunology from Imperial College London, who conducts vaccine studies aiming to improve mucosal vaccine efficacy by targeting activated dendritic cells.

The Pope lab fellows are currentIy funded by individual grants from the National Institutes of Health, with additional support to Turville from USAID and the Australian National Health and Medical Research Council.

\section{ECafrique: Meeting an Unmet Need}

\section{$\mathrm{E}$} MERGENCY CONTRACEPTION (EC) fills an important niche in the range of contraceptive options available to women and couples. EC refers to several contraceptive methods that can be used to prevent pregnancy after rape, failure of a contraceptive method, and/or other acts of unprotected sex.

Established in 2003 under the auspices of the Population Council, the African Forum on Emergency Contraception, or ECafrique, is a bilingual, international network of health care and business professionals seeking to expand the availability of EC services in Africa. Almost every country in sub-Saharan Africa is represented among ECafrique's over 200 institutional and individual members.

ECafrique supports two broad sets of activities. It undertakes research, advocacy, and service-delivery interventions at the country level; and it disseminates information on improving access to quality EC services regionally. The network informs the media and links national regulatory agencies and service providers with local pharmaceutical companies to encourage registration and production of high-quality EC products in Africa. It publishes a quarterly bulletin in French and English covering critical issues in EC. Circulation exceeds 2,000 electronic and hard copies.

The Secretariat of ECafrique is headquartered at the Council's Nairobi office, with program associate John Skibiak serving as network coordinator. Skibiak was elected last year to the steering committee of the International Consortium on Emergency Contraception (ICEC), of which the Council is a founding member. ECafrique facilitates communication between its members and those of the ICEC and other regional EC networks, particularly those in Latin America and the Arab-speaking world. -

ECafrique is funded by the William and Flora Hewlett Foundation and the Compton Foundation.

\section{Small Grants Aim for Big Results}

T HE POPULATION COUNCIL is collaborating with the Bill and Melinda Gates Institute for Population and Reproductive Health of Johns Hopkins University in awarding grants for small-scale, innovative projects in Pakistan. Experienced researchers are teamed with investigators just entering the field on projects that address key reproductive health issues, with the aim of building research capacity and filling knowledge gaps.

In India, the Council is administering the Health and Population Innovation Fellowship program (formerly the MacArthur Fund for Leadership Development) with the support of the John D. and Catherine T. MacArthur Foundation. The program is open to mid-career professionals who have leadership potential and the capacity to help shape policy and public debate in the fields of population and reproductive health. The program is focused in particular on maternal mortality and morbidity and the sexual and reproductive health and rights of young people. Twelve grants have been awarded since 2004 .

\section{Year-end Gifts}

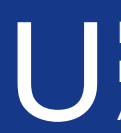

NRESTRICTED GIFTS TO THE POPULATION COUNCIL'S ANNUAL FUND provide core support for the Council's research and evidence-based advocacy, and its population, health, and development activities.

The Population Council is a nonprofit $501(c)(3)$ organization. Your gift is tax deductible in the United States in accordance with Internal Revenue Service regulations.

We thank the many individuals and foundations that already have made a gift to the 2005 Annual Fund. There is still time to contribute or make an additional gift prior to December 31, 2005. Cash gifts can be made by check or credit card as well as online at www.popcouncil.org/ supporting/secureorder.html.

The Council also welcomes gifts of appreciated securities, bequests, charitable remainder and lead trusts, and designations of the Council as beneficiary of insurance policies or pension plans. For further information contact Ruth Kalla Ungerer, Director of Development, Population Council, One Dag Hammarskjold Plaza, New York, NY 10017, (212) 339-0515, or rungerer@popcouncil.org. 
Momentum is a semiannual newsletter of the Population Council. Information may be reproduced without permission, provided it is distributed free of charge and the source is acknowledged. The Council is an international, nonprofit, nongovernmental organization that seeks to improve the well-being and reproductive health of current and future generations around the world and to help achieve a humane, equitable, and sustainable balance between people and resources. The Council conducts biomedical, public health, and social science research and helps build institutional capacity in developing countries. Established in 1952,

the Council is governed by an international board of trustees. Its New York headquarters supports a global network of 20 regional and country offices.

Writer Suzie Elliott

Editor Ruth Kalla Ungerer

Copyeditor Robert Heidel

Designers Y. Christina Tse, Mike Vosika

REGIONAL OFFICES

Latin America and the Caribbean:

Mexico City, Mexico

South and East Asia: New Delhi, India

Sub-Saharan Africa: Accra, Ghana West Asia and North Africa: Cairo, Egypt ISSN 1535-0525

(C) 2005 The Population Council, Inc. Printed in the USA on recycled paper

\section{N S I D E}

The Navrongo Experiment

An MDG That Can Be Met

On-the-ground Dissemination

\section{African Dreams}

Sowing Innovation

Swahili Translation of Council Publication on Fistula Lauded

Dissemination: Making Results Known

\section{Computerized Interviews:}

More Accurate Data?

A "Win-Win" for Science

ECafrique: Meeting an Unmet Need

Small Grants Aim for Big Results

Year-end Gifts

STAY CONNECTED

We want to be sure all Population Council alumni have the opportunity to stay in touch through Momentum. Contact Rob O'Sullivan, manager, Annual Fund and alumni relations, at 212-339-0511 or rosullivan@ popcouncil.org to share your news or comments about Council projects.

Photo credits-page 1, page 2 (top): Melissa May/Population Council; page 2 (bottom): Navrongo Health Research Centre; page 5 : Karen Tweedy-Holmes/Population Council

\section{News from the Population Council}

December 2005

\section{Nobel Laureate, Financier Elected to Board of Trustees}

$\mathrm{N}$ OBEL PRIZE WINNER AND HARVARD PROFESSOR AMARTYA SEN AND FINANCIER AND FORMER U.S. TREASURY OFFICIAL DARCY BRADBURY were elected to the Population Council's Board of Trustees at its June meeting, joining 15 other academic, business, and intellectual leaders from eight countries.

“Darcy Bradbury's financial management expertise and her commitment to reproductive health and Amartya Sen's knowledge of international development and human rights are potent additions to the board's collective knowledge," said Council president Peter J. Donaldson. "We are delighted that the Council's mission continues to attract such distinguished individuals."

Bradbury is a managing director of The Blackstone Group, a pri- vate investment and advisory firm. She is also an experienced trustee, serving on several boards including the Women's Campaign Fund, a nonpartisan group dedicated to “preserving access to reproductive choice by helping elect progressive women to political office," and the Nurse-Family Partnership, which works with first-time, impoverished mothers to improve the health and development of women and their children. Bradbury began her career as an investment banker, eventually moving into government service as New York City's Deputy Comptroller for Finance. She was appointed to the U.S. Department of the Treasury during the Clinton administration, first as Deputy Assistant Secretary for Federal Finance and later as Assistant Secretary for Federal Markets.

Sen is Lamont University Professor and Professor of
Economics and Philosophy at Harvard University. His previous academic appointments include the Delhi School of Economics, Jadavpur University, the London School of Economics, Oxford University, and Trinity College. He has served as president of the Econometric Society, the Indian Economic Association, the American Economic Association, and the International Economic Association. Sen has written or edited 25 books. His latest books are The Argumentative Indian: Writings on Indian History, Culture and Identity and Identity and Violence: The Illusion of Destiny. His Poverty and Famines was called "a key contribution to development economics" by the Royal Swedish Academy of Sciences when it awarded him the 1998 Nobel Prize in Economics. 